\title{
Biodiversity and Conservation Status of a Beech (Fagus sylvatica) Habitat at the Southern Edge of Species'Distribution
}

\author{
Rosario Tejera, María Victoria Núñez, Ana Hernando, \\ Javier Velázquez and Ana Pérez-Palomino
}

Additional information is available at the end of the chapter

http://dx.doi.org/10.5772/51365

\section{Introduction}

The aim of Habitats Directive (European Council, 1992) is "to contribute towards ensuring biodiversity through the conservation of natural habitats and of wild fauna and flora in the European territory of member states" (Article 2.1). This directive identifies a set of natural habitats and wild species of fauna and flora of Community interest (Annexes I and II of the Directive) and establishes the requirement to maintain a favourable conservation status. Therefore, Member States designate Special Protection Areas (SPAs), which are provisional sites of Community Importance (SCIs).

To ensure its enforcement, Member States should establish the necessary conservation measures involving, if necessary, appropriate management plans (Article 6.1).

According to the Article 1 of the Directive, the state of conservation of natural habitat is considered favourable when:

- its natural range and areas within that range are stable or increasing and

- the specific structure and functions necessary for long-term viability exist and are likely to continue to exist in the foreseeable future and

- the status of its typical species is favourable.

Member states have implemented different strategies for evaluating the conservation status of habitat types and species of Community interest, basing on both the European Commission reports (European Commission, 1995, European Commission, 2006, Shaw and Wind, 1997)) and scientific research (Bock et al., 2005, Dimitriou et al., 2006, Lang and Langanke, 2005, Noss, 1990, Noss, 1999, Roberts-Pichette, 1998, Simboura and Reizopoulou, 2007). 
In addition, some Member States have developed their own methodologies for assessing the conservation status, such as Germany, Austria, the Netherlands, Portugal, Spain and the United Kingdom (Velázquez et al., 2010). These previous studies often propose numerical indicators and have been applied at regional or national levels (Cantarello, 2008).

In Spain, in 2009 the Ministry of Rural and Marine Environment issued a set of guidelines at national level to assess the conservation status of habitats and species of Community interest (AUCT. PL. , 2009). The main objectives of these guidelines are to identify and adequately describe the 117 habitat types and typify their conservation status.

\section{Objetives}

The objective of this study was to determine the conservation status of habitat 9120 - Atlantic acidophilous beech forests with Ilex and sometimes also Taxus (Quercion robori-petraeae or IliciFagenion) within the beech forest of "Dehesa del Moncayo" (Spain) by applying the methodology provided by the Spanish Ministry. This implies a revision of the methodology at local level.

\section{Methodology}

The conservation status of habitats is assessed according to four general factors (European Commission, 2006): range and area occupied by the habitat, typical species, structure and function and future perspectives (Table 1). Each one can take the value of favourable, unfavourable-inadequate, unfavourable-bad or unknown. The overall assessment of the conservation status arises by combining the values obtained in Table 2 with the General Assessment Matrix (European Commission, 2006)

\begin{tabular}{|l|l|}
\hline \multicolumn{1}{|c|}{ FACTOR } & \multicolumn{1}{c|}{ INDICATOR } \\
\hline Range and area occupied & Area (ha) and trend \\
\hline Typical species & presence and abundance of typical species \\
\hline \multirow{4}{*}{ Structure and function } & Dead wood \\
\cline { 2 - 3 } & Forest structure \\
\cline { 2 - 3 } & Fragmentation \\
\cline { 2 - 3 } & Presence of Picidae \\
\cline { 2 - 3 } & Degree of defoliation \\
\hline Future prospects & Current and potential threats \\
\hline
\end{tabular}

Table 1. Adaptation of the methodology for the habitat 9120. 


\begin{tabular}{|c|c|c|c|c|}
\hline \multirow[t]{2}{*}{ PARAMETER } & \multicolumn{4}{|c|}{ CONSERVATION STATUS } \\
\hline & $\begin{array}{l}\text { Favourable } \\
\text { (green) }\end{array}$ & $\begin{array}{l}\text { Unfavourable- } \\
\text { inadecuate } \\
\text { (amber) }\end{array}$ & $\begin{array}{l}\text { Unfavourable-bad } \\
\text { (red) }\end{array}$ & Unknown \\
\hline $\begin{array}{l}\text { Distribution } \\
\text { area (range) }\end{array}$ & $\begin{array}{l}\text { The range of } \\
\text { habitat is stable } \\
\text { (loss and } \\
\text { expansion are } \\
\text { balanced) or } \\
\text { increasing and is } \\
\text { not less than the } \\
\text { "favourable area } \\
\text { of reference" }\end{array}$ & $\begin{array}{l}\text { Any situation } \\
\text { other than } \\
\text { those described } \\
\text { in "green" or } \\
\text { "red" }\end{array}$ & $\begin{array}{l}\text { Large decrease in the } \\
\text { range (equivalent to a } \\
\text { loss of more than } 1 \% \\
\text { per year over a period } \\
\text { specified by the EC, } \\
\text { other thresholds can } \\
\text { be used but should be } \\
\text { explained in Annex D } \\
\text { Or the range is more } \\
\text { than } 10 \% \text { below the } \\
\text { "favourable reference } \\
\text { range }\end{array}$ & $\begin{array}{l}\text { Not } \\
\text { available or } \\
\text { insufficient } \\
\text { reliable } \\
\text { information }\end{array}$ \\
\hline $\begin{array}{l}\text { Area occupied } \\
\text { by the habitat } \\
\text { within the } \\
\text { range }\end{array}$ & $\begin{array}{l}\text { The area occupied } \\
\text { by the habitat is } \\
\text { stable (loss and } \\
\text { expansion are } \\
\text { balanced) or } \\
\text { increasing and is } \\
\text { not less than the } \\
\text { "favourable area } \\
\text { of reference " and } \\
\text { without major } \\
\text { changes in the } \\
\text { distribution } \\
\text { pattern within the } \\
\text { range as a whole } \\
\text { (if data are } \\
\text { available for } \\
\text { evaluation) }\end{array}$ & $\begin{array}{l}\text { Any situation } \\
\text { other than } \\
\text { those described } \\
\text { in "green" or } \\
\text { "red" }\end{array}$ & $\begin{array}{l}\text { Large decrease of the } \\
\text { surface (equivalent to } \\
\text { a loss of more than } 1 \% \\
\text { per year over a period } \\
\text { specified by the MS, } \\
\text { other thresholds can } \\
\text { be used but should be } \\
\text { explained in Annex D } \\
\text { Or with losses } \\
\text { (negative changes) in } \\
\text { the pattern of } \\
\text { distribution within } \\
\text { the range } \\
\text { Or the current } \\
\text { surface is more than } \\
10 \% \text { below the } \\
\text { "favourable reference } \\
\text { range" }\end{array}$ & $\begin{array}{l}\text { Not } \\
\text { available or } \\
\text { insufficient } \\
\text { reliable } \\
\text { information }\end{array}$ \\
\hline $\begin{array}{l}\text { Structure and } \\
\text { functions }\end{array}$ & $\begin{array}{l}\text { Structures and } \\
\text { functions } \\
\text { (including typical } \\
\text { species) in good } \\
\text { condition and } \\
\text { without } \\
\text { significant } \\
\text { damage/pressure }\end{array}$ & $\begin{array}{l}\text { Any situation } \\
\text { other than } \\
\text { those described } \\
\text { in "green" or } \\
\text { "red" }\end{array}$ & $\begin{array}{l}\text { More than } 25 \% \text { of the } \\
\text { habitat is } \\
\text { unfavourable in terms } \\
\text { of its specific } \\
\text { structures and } \\
\text { functions (including } \\
\text { typical species) }\end{array}$ & $\begin{array}{l}\text { Not } \\
\text { available or } \\
\text { insufficient } \\
\text { reliable } \\
\text { information }\end{array}$ \\
\hline
\end{tabular}




\begin{tabular}{|c|c|c|c|c|}
\hline $\begin{array}{l}\text { Future } \\
\text { prospects } \\
\text { (regarding } \\
\text { range, area } \\
\text { covered and } \\
\text { structure and } \\
\text { function) }\end{array}$ & $\begin{array}{l}\text { Future prospects } \\
\text { are excellent / } \\
\text { good, no } \\
\text { significant effects } \\
\text { of future threats, } \\
\text { the long-term } \\
\text { viability is } \\
\text { guaranteed }\end{array}$ & $\begin{array}{l}\text { Any situation } \\
\text { other than } \\
\text { those described } \\
\text { in "green" or } \\
\text { "red" }\end{array}$ & $\begin{array}{l}\text { Future prospects are } \\
\text { bad, serious impacts } \\
\text { of threats, the long- } \\
\text { term viability is not } \\
\text { guaranteed }\end{array}$ & $\begin{array}{l}\text { Not } \\
\text { available or } \\
\text { insufficient } \\
\text { reliable } \\
\text { information }\end{array}$ \\
\hline $\begin{array}{l}\text { Overall } \\
\text { assessment of } \\
\text { conservation } \\
\text { status }\end{array}$ & $\begin{array}{l}\text { All "green" or } \\
\text { three "green" and } \\
\text { one "unknown" }\end{array}$ & $\begin{array}{l}\text { Any situation } \\
\text { other than } \\
\text { those described } \\
\text { in "green" or } \\
\text { "red" }\end{array}$ & $\begin{array}{l}\text { Two or more } \\
\text { "unknown" combined } \\
\text { with "green" or all } \\
\text { "unknown" }\end{array}$ & $\begin{array}{l}\text { Not } \\
\text { available or } \\
\text { insufficient } \\
\text { reliable } \\
\text { information }\end{array}$ \\
\hline
\end{tabular}

Table 2. General Assessment Matrix

\subsection{Distribution area and area occupied}

The distribution area can be defined as "the current habitat areas " (AUCT. PL. , 2009). It aims to identify changes of distribution patterns of the habitat within the range. This factor makes sense at the biogeographic region scale. However, the range does not apply at the local level.

The area occupied assesses the area covered by the habitat in the study area and its trend:

1. Area occupied by habitat in the study area (in hectares).

2. Date of assessment.

3. Trend of area (stable, increasing, decreasing or unknown).

4. Magnitude of the trend.

5. Period of trend.

6. Reasons for the trend.

The concept of "Favourable Area of Reference" (FAR) shown on the General Assessment Matrix is defined as "the minimum area required within a biogeographic region to ensure long-term viability of a type of habitat" (European Commission, 2006). Neither this concept is of application for the current study, since it is a study at the local scale.

\section{- $\quad$ Measuring procedure}

For the present study, the vegetation map of the Moncayo Natural Park has been used. We have distinguished three main types of vegetation: beech (used for extracting charcoal), scot pine reforestated in the 19th century and natural Pyrenean oaks (Gallo Manrique, 2011).

- $\quad$ Assessment of conservation status

The conservation status was assessed based on the trend of the area occupied, giving a value of zero to the status in 2000, as proposed in the methodology. 


\subsection{Typical species}

This factor considers the presence and viability of populations of typical species. That is, those that are indicators of habitat status. They can also be defined as those species relevant to maintain the habitat in a favourable conservation status, either because of their abundance or because of their influence in the ecological functions.

Typical species of the habitat 9120 are:

Flora: Yew (Taxus baccata L.), holly (Ilex aquifolium L.), Lobaria pulmonaria L.

Amphibians: Salamander (Salamandra salamandra)

Mammals: Gray dormouse (Glis glis)

Birds: White-backed woodpecker (Dendrocopus leucotus), Black Woodpecker (Dryocopus martius), Nuthatch (Sitta Europea), Treecreeper (Certhia familiaris), Pied flycatcher (Ficedula hypoleuca), Marsh Tit (Parus palustris)

Invertebrates: saproxylic invertebrates: Elona quimperiana, Rosalia alpina, Osmoderma eremita, Limoniscus violaceus, Cerambyx cerdo, Lucanus cervus, Gnorimus variabilis, Caliprobola speciosa.

- $\quad$ Measuring procedure

The method used was based on observations of presence/absence of typical species during the field work reinforced with the wildlife catalog of Moncayo Natural Park (Gobierno de Aragón, 2002)

- $\quad$ Assessment of conservation status

It is not imperative that a particular location holds all or most of its typical species for a favourable conservation status (European Commission, 2006). But the set of all the habitats at the national or biogeographic scale must have long-term viable populations of all or many of the typical species of the habitat.

Since this study covers a small area of habitat 9120 in Spain, we assessed the number of typical species present in the forest. The result of this factor must be consistent with the structure and function factors.

\subsection{Structure and function}

Structure and function define the quality of habitat 9120 through four parameters: dead wood, stand structure, fragmentation, presence of Picidae and degree of of defoliation.

To determine the overall status of the structure and function, each indicator takes a value (0: unfavourable-bad, 1: unfavourable-inadequate, 2: favourable). The overall status of the structure and function can be unfavourable-bad - for results below $40 \%$ of maximum punctuation - , unfavourable-inadequate - from 40 to $75 \%$ - , and favourable - above $75 \%$. 


\subsubsection{Dead Wood}

This indicator measures dead wood $\left(\mathrm{m}^{3} / \mathrm{ha}\right)$, separating it according to: species, standing or fallen, size and level of decomposition.

- $\quad$ Measuring procedure

The inventory of dead wood was done by strip-plots $500 \mathrm{~m}$ long and $20 \mathrm{~m}$ wide ( $1 \mathrm{ha}$ ), as proposed in the Spanish methodology (Olano and Peralta de Andrés, 2009). In these plots we measured dead wood - both standing and fallen - , diameter, length, species, and degree of decomposition.

The degree of decomposition was assessed according to the following criteria (Table 3).

\begin{tabular}{|l|l|}
\hline Degree of decomposition & Description \\
\hline Level 1 & Healthy wood, with bark; wood intact \\
\hline Level 2 & Healthy wood, beginning of the bark loss \\
\hline Level 3 & Wood beginning to rot away. Without bark \\
\hline Level 4 & Very rotten wood, full of holes \\
\hline Level 5 & Completely rotten wood that breaks when touched \\
\hline
\end{tabular}

Table 3. Degree of d criteria

\section{- $\quad$ Assessment of conservation status}

Dead wood in forests ranges from 10 to $150 \mathrm{~m}^{3} /$ ha (Müller and Bütler, 2010). According to these authors, most species linked to dead wood seem to be present in hardwood forests for volumes between 30 and $50 \mathrm{~m}^{3} / \mathrm{ha}$.

- Unfavourable-Bad: less than $10 \mathrm{~m}^{3}$ of dead wood per hectare.

- Unfavourable-inadequate: 10 to $30 \mathrm{~m}^{3}$ of dead wood per hectare, with at least $30 \%$ of deadwood above $30 \mathrm{~cm}$ diameter and $20 \%$ of standing dead wood.

- Favourable: more than $30 \mathrm{~m}^{3}$ of dead wood per hectare, with at least $12 \mathrm{~m}^{3} / \mathrm{ha}$ of dead wood above $30 \mathrm{~cm}$ diameter and at least $4 \mathrm{~m}^{3} / \mathrm{ha}$ of standing dead wood. It is important that dead wood presents all stages of decomposition and it is distributed throughout the habitat.

\subsubsection{Forest structure}

Forest structure is evaluated according to three indicators: abundance of overmature trees (trees with dbh above $45 \mathrm{~cm}$ ), structural diversity and species diversity. It is necessary to assess the number of stems/ha per diameter class and indicate the proportion of species.

To determine the overall status of forest structure, each indicator has a value (0: unfavourable-bad, 1: unfavourable-inadequate, 2: favourable). The overall status of the structure and function is unfavourable-bad - for results below $40 \%$ of the maximum 
punctuation -, unfavourable-inadequate - from 40 to $75 \%$ - , and favourable - above $75 \%$.

- $\quad$ Measuring procedure

We inventoried diameter and species in circular plots $10 \mathrm{~m}$ radius, located at the points 100 , 300 and $500 \mathrm{~m}$ of the strip-plots used for the inventory of dead wood.

- $\quad$ Assessment of conservation status

Overmature tree $(\mathrm{dbh}>45 \mathrm{~cm})$ :

- Unfavourable-Bad: less than 5 trees/ha

- Unfavourable-inadequate: 6 to 10 trees/ha.

- Favourable: above 10 trees/ha

Species diversity:

- Unfavourable-Bad: less than 5 trees $(\mathrm{dbh}>15 \mathrm{~cm}) /$ ha of other native tree species.

- Unfavourable-inadequate: 5 to 10 trees $(\mathrm{dbh}>15 \mathrm{~cm}) /$ ha of other native tree species

- Favourable: above 10 trees $(\mathrm{dbh}>15 \mathrm{~cm}) /$ ha of other native tree species

Structural diversity:

- Unfavourable-Bad: $90 \%$ trees in the same diameter class (classes of $20 \mathrm{~cm}$ ).

- Unfavourable-inadequate: from $80 \%$ to $90 \%$ trees in the same diameter class (classes of $20 \mathrm{~cm})$.

- Favourable: less than $80 \%$ trees in the same diameter class (classes of $20 \mathrm{~cm}$ ).

\subsubsection{Fragmentation}

This indicator evaluates whether the habitat is a continuous patch of sufficient extent to ensure species survival or, conversely, is composed of individual patches.

Fragmentation is a very important element for forest communities that affects the quality of habitat and causes loss of species (Telleria and Santos, 2001). In beech forests, typical flora and fauna species are strongly affected by the edge effect due to their dependence on low light and high relative humidity.

- Measuring procedure

Fragmentation is quantified by comparing the total habitat area with the surface free of edge effect (effective area). We considered an edge effect of $30 \mathrm{~m}$ from the margins of the patches.

- Assessment of conservation status

- Unfavourable-Bad: ratio between surface without edge effect and total area less than $80 \%$.

- Unfavourable-inadequate: ratio between surface without edge effect and total area from 80 to $90 \%$

- Favourable: ratio between surface without edge effect and total area above $90 \%$. 


\subsubsection{Presence of Picidae}

Picidae are known for tapping on tree trunks in order to find insects living in crevices in the bark and to excavate nest cavities. Some of these species require old forests with abundant dead wood, both standing and fallen. The presence of Picidae is a good indicator of habitat quality and conservation status.

- $\quad$ Measuring procedure

We performed a visual observation of cavities in the circular plots of the inventory. Additionally we used bibliographic survey (Gobierno de Aragón, 2002).

- Assessment of conservation status

- Unfavourable-Bad: no Picidae nesting.

- Unfavourable-Inadequate: Only Great Spotted Woodpecker (Dendrocopos major) nesting.

- Pro: woodpecker White-backed Woodpecker (Dendrocopos leucotos) or Black Woodpecker (Dryocopus martius) nesting

\subsubsection{Degree of defoliation}

This indicator belongs to the group of indicators for the maintenance of health and vitality of forest ecosystems and is considered to be the main indicator of health status (MCPFE, 2002).

In Spain, there is a network of Forest Damage Assessment following the European methodology (International Cooperative Programme on Forests). In Moncayo Natural Park there are 5 plots for that network, but none of them within the beech forest "Dehesa del Moncayo".

- Measuring procedure

We visually assessed the percentage of defoliation in the circular inventory plots

- Assessment of conservation status

We used the thresholds of European Forest Damage Assessment Network (Table 4)

\begin{tabular}{|c|c|c|}
\hline Defoliation class & $\%$ defoliation & Description \\
\hline 0 & $0-10 \%$ & No defoliation \\
\hline 1 & $>10-25 \%$ & Minimum \\
\hline 2 & $>25-60 \%$ & Moderate \\
\hline 3 & $>60-<100 \%$ & High \\
\hline 4 & $100 \%$ & Dead tree \\
\hline
\end{tabular}

Table 4. Criteria for assessing defoliation levels 


\subsection{Future perspectives}

This factor refers to the long-term viability of a habitat considering possible threats, typical species and structure and function factors.

- $\quad$ Measuring procedure

We evaluated the main past and present impacts and the possible future threats that may affect the long term-viability of the habitat.

- $\quad$ Assessment of conservation status

- Unfavourable: The future scenario does not ensure the long-term viability of habitat 9120

- Favourable: The future scenario ensures the long-term viability of habitat 9120

\section{Case study}

\subsection{Study area}

The study area was the 1494 ha forest " Dehesa del Moncayo" within Moncayo Natural Park (Aragón, Spain) (Fig. 1). It is also included in the Natura 2000 Network as part of SCI ES2430028 "Moncayo" and SPA ES0000297 "Sierra del Moncayo-the-Fayos Sierra Arms" due to six habitats of interest. One of them is habitat 9120 Atlantic acidophilous beech forests with Ilex and sometimes also Taxus in the shrublayer (Quercion robori-petraeae or Ilici-Fagenion).

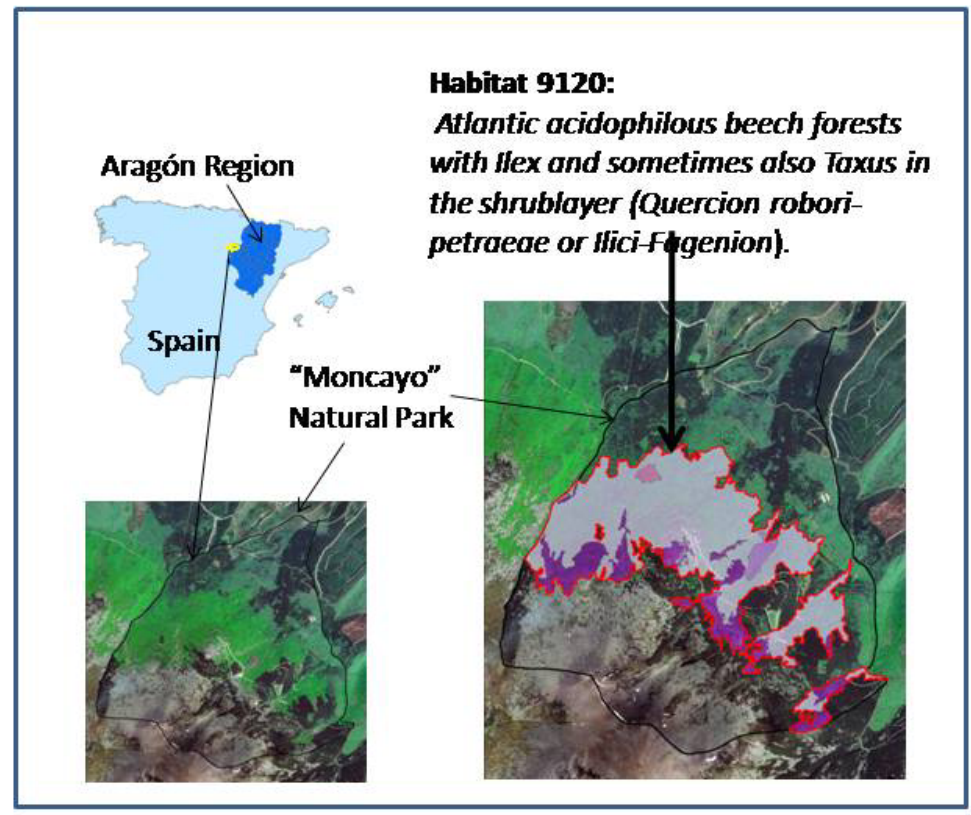

Figure 1. Location scheme 
The forest is at the southern edge of the Mediterranean region. However, it is considered an "Atlantic island" due to the altitude and the NW-SE aspect. The Moncayo beech forest is between 1100 and $1900 \mathrm{~m}$ a.s.l. facing north or northeast with slopes between 20 and 50\%. It has been mainly used for charcoal until 1940, since then it has evolved into a high polewood. It used to be also used for timber but, due to the poor quality of timber, cuttings have been infrequent. In 1978 it was declared Natural Park.

We distinguished four different forest types:

Beech forest (Fagus sylvatica)

This is a typical high density beech forest with holly (Ilex aquifolium) and blueberry(Vaccinium myrtillus) in less dense areas. It covers 360 ha (Table 5).

Fagus sylvatica on screes

Small and branched isolated beech trees on rocky abrupt areas.

Rangeland of Fagus sylvatica

It is an area of small size (9.92 ha) used for grazing until 1920. As a result, big trees are accompanied by smaller trees.

Fagus sylvatica with heather (Erica sp.)

Beech forest with dense heather and other tree species such as Rebollo oak (Quercus pyrenaica) and Scots pine (Pinus sylvestris)

\begin{tabular}{|l|l|l|}
\hline \multirow{2}{*}{ Forest types } & \multicolumn{2}{|l|}{ Area } \\
\cline { 2 - 3 } & (ha) & \multicolumn{2}{l|}{$(\%)$} \\
\hline Beech forest (Fagus sylvatica) & 360,61 & 76,82 \\
\hline Fagus sylvatica on scree & 94,76 & 20,19 \\
\hline Rangeland of Fagus sylvatica & 9,92 & 2,11 \\
\hline Fagus sylvatica with heather (Erica sp.) & 4,13 & 0,88 \\
\hline TOTAL & 469,42 & - \\
\hline
\end{tabular}

Table 5. Forests types area (ha and \%)

"Fagus sylvatica on scree" is assigned to habitat 8130 Mediterranean and thermophilous screes. Therefore it was excluded of the conservation status assessment. 


\subsection{Field survey}

We performed a simple random pilot sampling inventory leaning on the network of paths. The pilot sampling was conducted over three consecutive days in July 2010.

The main objective of the pilot sampling was to calculate the variance and to determine whether the error was admissible or the inventory had to be strengthened with new sampling plots.

"Fagus sylvatica with heather" was excluded because it is a small area where the abundance of heather and the low density of trees do not justify the inventory.

\subsection{Measuring procedure}

\subsubsection{Sampling units}

We measured dead wood in four strip plots of $500 \times 20 \mathrm{~m}$ and forest structure in 12 circular plots of $10 \mathrm{~m}$ radius ( 3 in each strip plot), distributed by forest type(Fig. 1).

It was decided to place them on the network of paths since this does not influence significantly the volume estimation of dead wood, due to narrow lanes (less than $1 \mathrm{~m}$ wide) and high bandwidth $(10 \mathrm{~m})$ both sides the path.

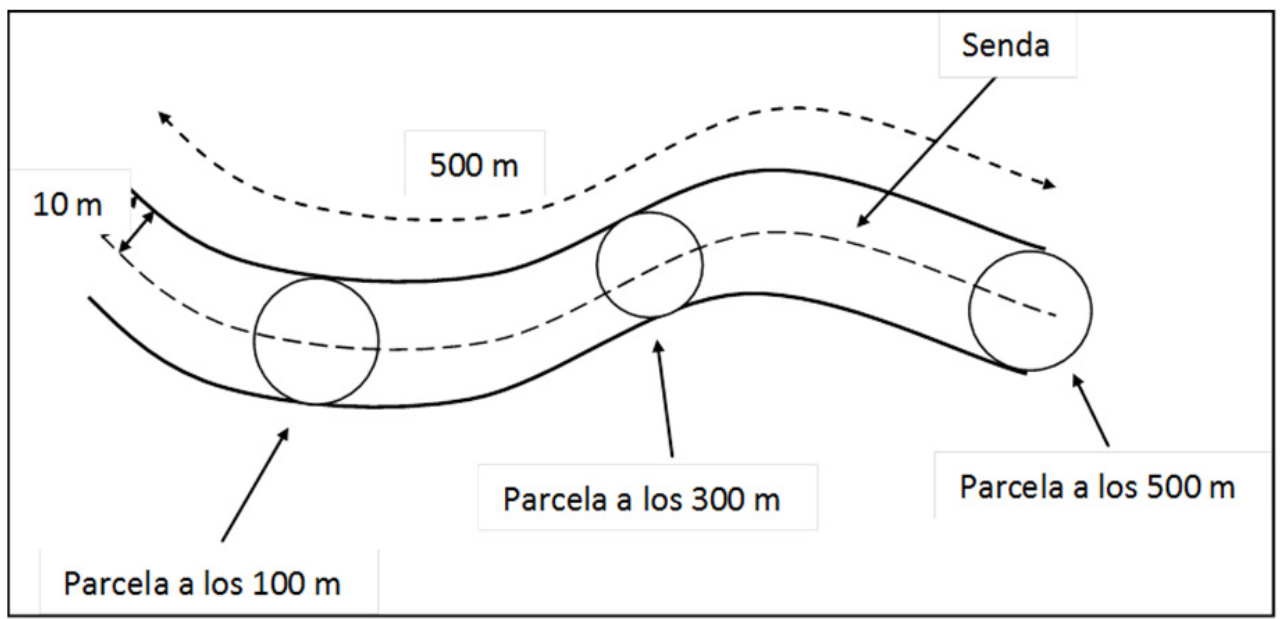

Figure 2. Sampling plots

We measured all dead wood on the ground from a minimum diameter of $10 \mathrm{~cm}$ (criterion given by the technical director of the study). Given the abundance of fine twigs on the 
ground and the large size of the sample plots ( $1 \mathrm{ha})$, measurement from $0 \mathrm{~cm}$ would have been impossible.

\subsubsection{Measured variables}

Variables from strip plots:

- Dead wood: Dead wood is classified into several groups: dead wood on the ground, standing dead trees, stumps and dead branches on living trees (Kirby et al., 1998). Diameter of the middle section (diameter at half the length of the fragment), length and level of decomposition was measured for dead wood on the floor.

Diameter at $1.30 \mathrm{~m}$ height, total height, and level of decomposition was assessed for standing dead wood.

Variables from circular plots:

- $\quad$ Forest structure: The reference methodology does not establish a minimum diameter for measuring forest structure. Following the technical director criterion, trees below $2.5 \mathrm{~cm}$ diameter were excluded. Therefore, for the rest of the trees we measured all diameters at $1.30 \mathrm{~m}$ height and recorded the species.

- Level of defoliation (by visual observation)

- number of cavities (natural or Picidae)

- number of trees below $2.5 \mathrm{~cm}$ diameter

- Mean height of the stand

- Description of the stand, indicating silvicultural characteristics, non target species, and a sketch/diagram/outline/schema of the vertical forest structure.

We performed a sheet for each plot.

\subsection{Field work results}

Analysis of variance (ANOVA) was performed for both variables to check significant differences between the two types of beech forest inventoried ("beech Fagus sylvatica" and "Rangeland of Fagus sylvatica"). The analysis showed no significant differences. So we adopted a single maximum admissible error for these variables.

When sampling dead wood, errors are generally quite high (Kirby et al., 1998, Van Wagner, 1982, Woodall et al., 2006, Woodall and Williams, 2005). Following Van Wagner (1982), in this study we assumed a $20 \%$ maximum admissible error.

Error for standing dead trees is higher than admissible (Table 8). However, lack of standing dead trees (Table 7) and heterogeneous distribution are typical of young beech forests.

Furthermore, the error for the variable basal area slightly exceeds the maximum so it was not considered necessary to reinforce the sampling. 


\begin{tabular}{|c|c|c|c|}
\hline \multirow{2}{*}{ strip plot } & CIRCULAR PLOT & $\mathrm{G}\left(\mathrm{m}^{2}\right)$ & $\mathrm{G}\left(\mathrm{m}^{2} / \mathrm{ha}\right)$ \\
\hline \multirow{3}{*}{1} & 1 & 0,46 & 14,60 \\
\cline { 2 - 4 } & 2 & 0,60 & 18,98 \\
\cline { 2 - 4 } & 3 & 0,75 & 23,88 \\
\cline { 2 - 4 } & 1 & 0,79 & 24,99 \\
\cline { 2 - 4 } & 2 & 1,79 & 56,90 \\
\cline { 2 - 4 } & 3 & 0,91 & 29,06 \\
\cline { 2 - 4 } & 1 & 1,11 & 35,24 \\
\hline \multirow{3}{*}{3} & 2 & 1,15 & 36,58 \\
\cline { 2 - 4 } & 3 & 0,96 & 30,48 \\
\cline { 2 - 4 } & 2 & 0,60 & 18,96 \\
\hline \multirow{3}{*}{4} & 3 & 0,61 & 19,53 \\
\hline
\end{tabular}

Table 6. Basal area (G) by circular plot

\begin{tabular}{|c|c|c|c|}
\cline { 2 - 4 } \multicolumn{1}{c|}{} & \multicolumn{3}{c|}{ Dead wood volume $\left(\mathrm{m}^{3} / \mathrm{ha}\right)$} \\
\hline strip plot & total & Standing dead wood & $\begin{array}{c}\text { dead wood on the } \\
\text { floor }\end{array}$ \\
\hline 1 & 3,71 & 0,83 & 2,88 \\
\hline 2 & 5,68 & 1,70 & 3,97 \\
\hline 3 & 4,88 & 0,91 & 3,97 \\
\hline 4 & 4,23 & 0,56 & 3,67 \\
\hline
\end{tabular}

Table 7. Dead wood results by plot

\begin{tabular}{|c|c|c|c|}
\hline VARIABLE & Mean & Variance & Error $(\%)$ \\
\hline Basal area $\left(\mathrm{m}^{2} / \mathrm{ha}\right)$ & 27,79 & 119,09 & 21,78 \\
\hline Dead wood on the floor $\left(\mathrm{m}^{3} / \mathrm{ha}\right)$ & 3,62 & 0,27 & 14,26 \\
\hline Standing dead wood $\left(\mathrm{m}^{3} / \mathrm{ha}\right)$ & 1,00 & 0,24 & 48,96 \\
\hline Total dead wood $\left(\mathrm{m}^{3} / \mathrm{ha}\right)$ & 4,63 & 0,72 & 18,36 \\
\hline
\end{tabular}

Table 8. Mean values, variance and error 


\section{Results for the conservation status assessment}

\subsection{Range}

The results for the area occupied factor according to the methodology are:

Area covered by habitat 9120 within "Dehesa del Moncayo": 374.65 has

Date: 2011.

Trend: stable/increasing.

Trend-period: 1975-2011.

Reasons for the trend: the absence of human influence and good regeneration capacity.

\begin{tabular}{|l|l|}
\hline Range & FAVUORABLE \\
\hline
\end{tabular}

\subsection{Typical species}

Typical 9120 habitat species present in "Dehesa del Moncayo" are the following:

Flora: Yew (Taxus baccata), holly (Ilex aquifolium) and Lobaria pulmonaria.

Holly is scarce except for some areas of low beech density. Yew and Lobaria pulmonaria are scarce or rare.

Birds: Nuthatch (Sitta European) and Pied flycatchers (Ficedula hypoleuca).

Invertebrates: Rosalia alpina and Cerambyx cerdo.

During the field work no typical species of fauna were inventoried.

Therefore, the conservation status for this factor is unfavourable-bad.

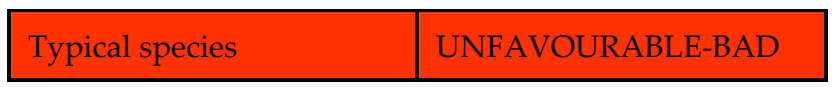

\subsection{Structure and function}

Snags are scarce and most of them are not large (Fig. 2)

\begin{tabular}{|c|c|c|c|}
\cline { 2 - 4 } \multicolumn{1}{c|}{} & \multicolumn{3}{c|}{ Volume of deadwood $\left(\mathrm{m}^{3} \mathrm{~m}^{3} / \mathrm{ha}\right)$} \\
\hline Strip-plot & Total & $\begin{array}{c}\text { Standing dead } \\
\text { wood }\end{array}$ & $\begin{array}{c}\text { Dead wood on } \\
\text { the floor }\end{array}$ \\
\hline 1 & 3.71 & 0.83 & 2.88 \\
\hline 2 & 5.68 & 1.70 & 3.97 \\
\hline 3 & 4.88 & 0.91 & 3.97 \\
\hline 4 & 4.23 & 0.56 & 3.67 \\
\hline Mean & 4.63 & $\mathbf{1 . 0 0}$ & 3.62 \\
\hline
\end{tabular}

Table 9. Volume of total deadwood - standing and on the floor - in each strip-plot 


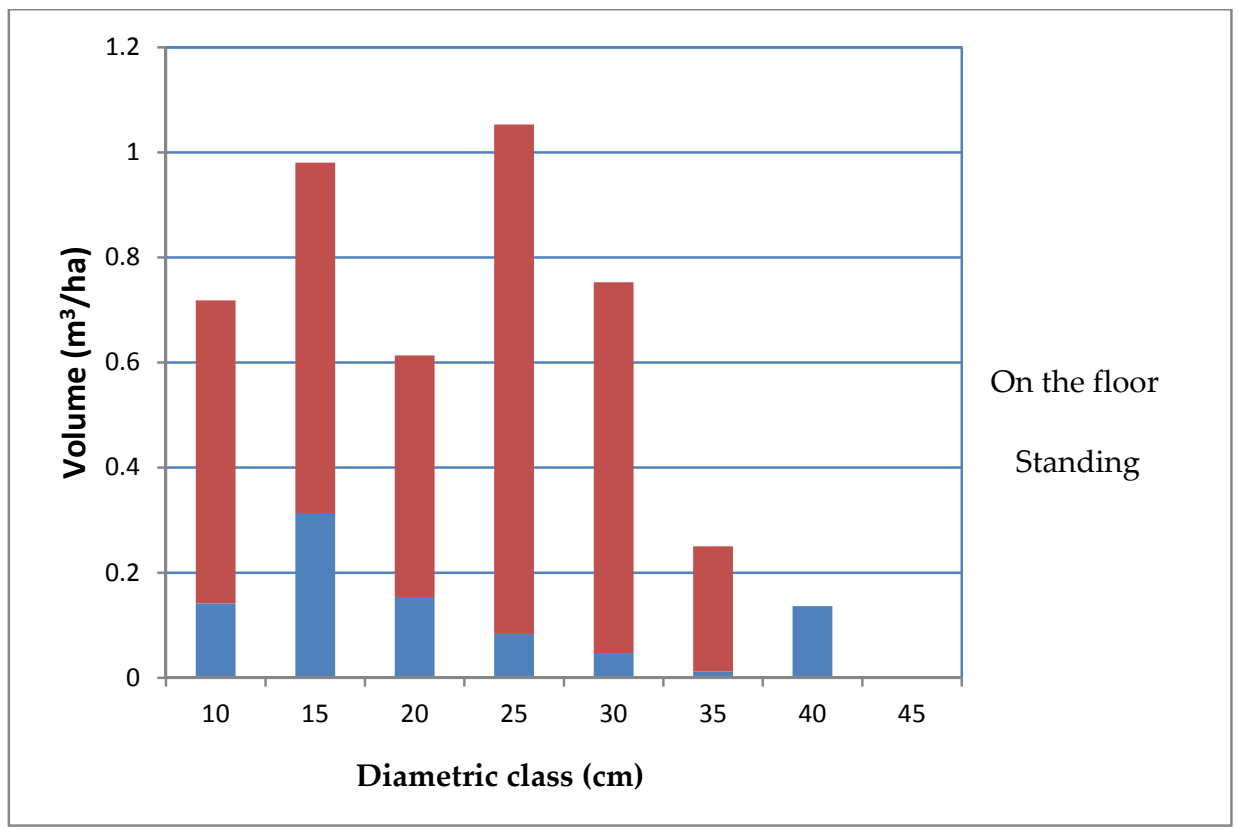

Figure 3. Volume $\left(\mathrm{m}^{3} / \mathrm{ha}\right)$ by diametric class and type of dead wood

The mean total volume of deadwood is below $10 \mathrm{~m}^{3} /$ ha (Table 9). Therefore, the conservation status is unfavourable-bad.

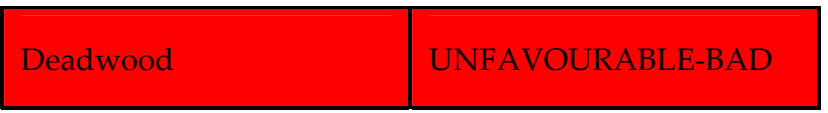

\subsubsection{Forests structure}

- Oversized trees: Only 4 oversized trees were sampled (all of them in the "Rangeland of Fagus sylvatica" forest type) involving a total of 9.8 tree/ha. An unfavourable-inadequate conservation status was assessed for this component.

- $\quad$ Species diversity: Density of non target species with dbh above $15 \mathrm{~cm}$ was 14.7 tree/ha. Based on thresholds proposed in the methodology, a favourable conservation status for this component was assessed.

- Structural diversity:

- Total density reaches 1320 trees/ha. Above 50\% of them are trees below $12.5 \mathrm{~cm} \mathrm{dbh}$. Regenerated beech $(\mathrm{dbh}<2.5 \mathrm{~cm}))$ is the most abundant diameter class, with $32.84 \%$ of total trees. Large trees are scarce.

- Less than $80 \%$ of trees group into the same diameter class (Fig. 3), so that the status regarding the structural diversity is favourable. 


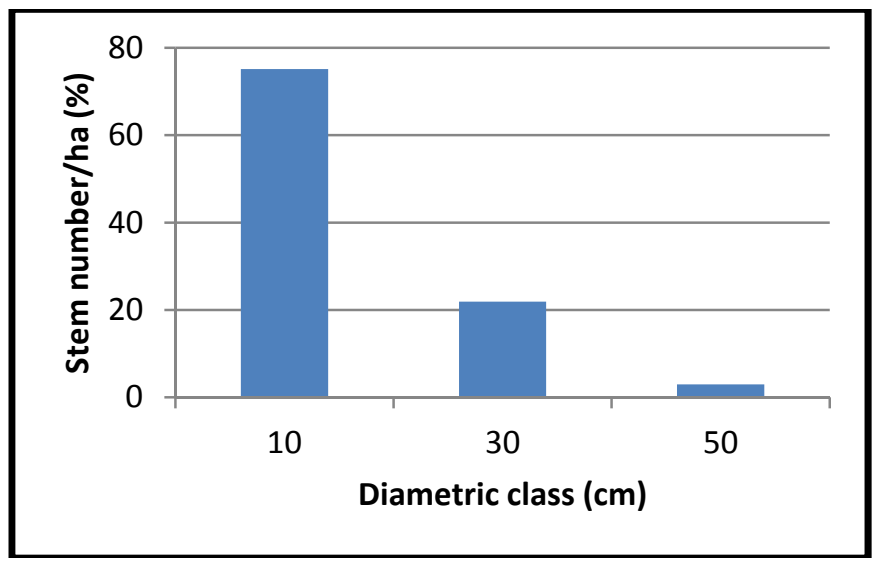

Figure 4. Tree distribution by diameter classes

Individual results (0: unfavourable-bad, 1: unfavourable-inadequate, 2: favourable) reach 5 of the 6 possible points. So the conservation status of forest structure indicator is favourable.

\section{\begin{tabular}{|l|l|}
\hline Forest structure & FAVOURABLE
\end{tabular}}

\subsubsection{Habitat fragmentation}

Total area is 374.65 and the effective area, 278.36 ha. This yields a ratio of $74.30 \%$ free surface of the edge effect. According to the thresholds in the methodology, this is an unfavourablebad status.

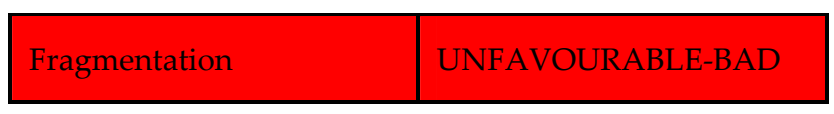

\subsubsection{Presence of Picidae}

The only species inventoried are Spotted woodpecker (Dendrocopos major), green woodpecker (Picus viridis) and Wryneck (Jynx torquilla) (experts information).

According to the thresholds established in the methodology, the conservation status is unfavourable-inadequate.

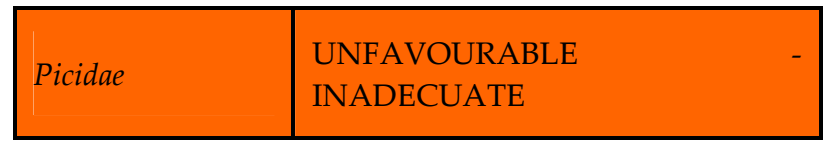




\subsubsection{Degree of defoliation}

Defoliation reaches $12.5 \%$. According to the pan-European forest monitoring criteria, defoliation level is low. Therefore, the conservation status is favourable.

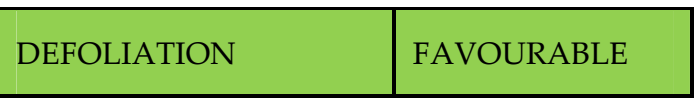

\subsubsection{Overall Conservation status of structure and function indicator}

The overall conservation status scores 5 points (50\% of maximum points), that means unfavourable-inadequate.

\begin{tabular}{|c|c|c|}
\hline INDICATOR & Conservation status & Points \\
\hline Dead wood & Unfavourable-bad & 0 \\
\hline Forest structure & Favourable & 2 \\
\hline Habitat fragmentation & Unfavourable-bad & 0 \\
\hline Picidae & Unfavourable-inadecuate & 2 \\
\hline Degree of defoliation & Favourable & \\
\hline
\end{tabular}

\section{Structure and function UNFAVOURABLE -INADECUATE}

\subsection{Future Prospects}

Given the low grazing pressure of herbivores, the control of public use and the low risk of fire, future prospects are favourable.

\section{\begin{tabular}{|l|l}
\hline Future Prospects & FAVOURABLE
\end{tabular}}

\subsection{Global conservation status}

Table 10 shows the results of the four general factors used to evaluate the conservation status of the habitat. 


\begin{tabular}{|l|r|l|}
\hline \multicolumn{1}{|c|}{ FACTOR } & Conservation status & $\begin{array}{c}\text { Global conservation } \\
\text { status }\end{array}$ \\
\hline Range & Favourable & \\
\hline Typical species & Unfavourable-bad & \multirow{2}{*}{ Unfavourable-bad } \\
\hline Structure and function & Unfavourable-inadecuate & \\
\hline Future Prospects & Favourable & \\
\hline
\end{tabular}

Table 10. Global Conservation Status for the 9120 habitat within "Dehesa del Moncayo" and final diagnosis

By applying the General Assessment Matrix (Table 2) criteria, we conclude that the conservation status of 9120 habitat within "Dehesa del Moncayo" is unfavourableinadequate.

\section{Discussion}

The methodology of this study is an important step for assessing the conservation status of habitats of Community interest. The reference values are based on scientific research which should be adjusted periodically.

When applying this methodology to the 9120 habitat we found some difficulties:

The area of distribution and area occupied had to be adapted locally since the General Assessment Matrix proposes the biogeographic region. This led to only consider the area occupied by the habitat.

Measurement procedure for Typical species has not been standarised yet. We used bibliographic survey that may not accurately represent population and species of our habitat. The conservation status of typical species was unfavourable-bad due to the scarcity of species of fauna. However there may be several abundant and viable populations and more research would be necessary.

Structure and function is the core of the conservation status assessment. This Indicator was unfavourable-inadequate. Only forest structure and level of defoliation parameters had a favourable outcome. Although forest structure result was favourable, tree distribution is far from an uneven-aged forest which is the most suitable structure for biodiversity (Camprodon and Plana, 2007). Therefore, more research studies on thresholds of structure and function should be developed. 
Procedures to measure dead wood have not been standarised yet either. Taking into account several studies (Kirby et al., 1998, Woodall and Williams, 2005) we considered that "line transect" method could be more efficient than "strip-plot" method and could allow dead wood on the floor to be measured from $0 \mathrm{~cm}$ instead of $2.5 \mathrm{~cm}$.

Finally, the overall conservation status unfavourable-inadequate shows the habitat is far from the favourable status. The lack of typical species of fauna is linked to the scarce dead wood and old trees with cavities. However, this is a young beech forest without productive exploitation since 1975 so the future prospects are favourable.

\section{Conclusions}

The Preliminary Ecological bases for the conservation of habitat types of Community interest in Spain (AUCT. PL., 2009) assesses the conservation status according to four general factors: range and area occupied, typical species, structure and function, and future prospects.

Although results showed an unfavourable conservation status, the current situation of the beech forest is the best one considering that it was highly harvested in the past. The future prospects are favourable and ensure the capacity of the forest to naturally achieve all the quality thresholds required, with no forest management actions.

Our results indicate that special attention must be paid to thresholds and that more accurate measurement procedures and assessment methods must be developed.

This methodology is an important and comprehensive starting point, however, it requires further applications to identify weaknesses and optimal measurement procedures.

\section{Author details}

Rosario Tejera

Research Group for Sustainable Management, Department of Economy and Forest Management E.T.S.I de Ingenieros de Montes, Technical University of Madrid (U.P.M), Ciudad Universitaria, Madrid, Spain

María Victoria Núñez

Research Group for Sustainable Management, Department of Projects and Rural Planning E.T.S.I de Ingenieros de Montes, Technical University of Madrid (U.P.M), Ciudad Universitaria, Madrid, Spain

Ana Hernando

Research Group for Sustainable Management, Department of Economy and Forest Management E.T.S.I de Ingenieros de Montes, Technical University of Madrid (U.P.M), Ciudad Universitaria, Madrid, Spain 
Javier Velázquez

Catholic University of Avila. C/ Los Canteros, Ávila, Spain

Ana Pérez-Palomino

E.T.S.I de Ingenieros de Montes, Technical University of Madrid (U.P.M), Ciudad Universitaria, Madrid, Spain

\section{Acknowledgement}

The research leading to these results has received funding from the Servicio Provincial de Medio Ambiente del Gobierno de Aragón and FEADER. We wish to thank all of the members of the research group "Silvanet" for their support and comments. We extend special thanks to Enrique Arrechea Veramendi for his cooperation and assistance and Miguel Valentín Gamazo for the English review.

\section{References}

AUCT. PL. (2009). Preliminary ecological basis for conservation of habitat types of Community interest in Spain Ministry of Rural and Marine Environment, Madrid.

Bock, M., Rossner, G., Wissen, M., Remm, K., Langanke, T., Lang, S., Klug, H., Blaschke, T. \& Vrscaj, B. (2005). Spatial indicators for nature conservation from European to local scale. Ecological indicators, 5, 322-338.

Camprodon, J. \& Plana, E. (2007). Conservación de la biodiversidad, fauna vertebrada y gestión forestal, Publicacions i Edicions Universitat de Barcelona.

Cantarello, E., Newton A.C. (2008). Identifying cost-effective indicators to assess the conservation status of forested habitats in Natura 2000 sites. Forest Ecology and Management, 256, 815-826.

Dimitriou, E., Karaouzas, I., Skoulikidis, N. \& Zacharias, I. (2006). Assessing the environmental status of Mediterranean temporary ponds in Greece. Annales De Limnologie-International Journal of Limnology, 42, 33-41.

European Commission (1995). Standard Data Form for Special Protection Areas (SPA) for sites eligible for identification as Sites of Community Importance (SCI) and for Special Areas of Conservation (SCA).

European Commission (2006). Assessment, monitoring and reporting under Article 17 of the Habitats Directive: Explanatory Notes \& Guidelines.

European Council (1992). Directiva 92/43/CEE del Consejo de 21 de mayo de 1992 relativa a la conservación de los hábitats naturales y de la fauna y flora silvestres. DO L 206 de 22.7.1992, p.7, Bruselas.

Gallo Manrique, P. (2011). 4ª Revisión del Proyecto de Ordenación del M.U.P. 251 "Dehesa del Moncayo", Tarazona (Zaragoza).

Gobierno de Aragón, D.d.M.A. (2002). Plan Rector de Uso y Gestión del Parque Natural del Moncayo. Zaragoza. 
Kirby, K.J., Reid, C.M., Thomas, R.C. \& Goldsmith, F.B. (1998). Preliminary estimates of fallen dead wood and standing dead trees in managed and unmanaged forests in Britain. Journal of Applied Ecology, 35, 148-155.

Lang, S. \& Langanke, T. (2005). Multiscale GIS tools for site management. Journal for Nature Conservation, 13, 185-196.

MCPFE (2002). Improved Pan-European Indicators for Sustainable Forest Management. Viena.

Müller, J. \& Bütler, R. (2010). A review of habitat thresholds for dead wood: a baseline for management recommendations in European forests. European Journal Forest Resource, $129,981-992$.

Noss, R.F. (1990). Indicators for monitoring biodiversity - A hierarchichal approach. Conservation Biology, 4, 355-364.

Noss, R.F. (1999). Assessing and monitoring forest biodiversity: a suggested framework and indicators. Forest Ecology and Management, 115, 135-146.

Olano, J.M. \& Peralta de Andrés, J. (2009). 9120 Hayedos acidófilos atlánticos con sotobosque de Ilex y a veces de Taxus (Quercinion robori-petraeae o Ilici-Fagenion). En: Bases ecológicas preliminares para la conservación de los tipos de hábitat de interés comunitario en España. (Ministerio de Medio Ambiente, y Medio Rural y Marino, Madrid.

Roberts-Pichette, P. (1998). Canada's Ecological Monitoring and Assessment Network with special reference to long-term biodiversity monitoring. Forest Biodiversity in North, Central and South America, and the Caribbean, 21, 47-56.

Shaw, P. \& Wind, P. (1997). Monitoring the condition and biodiversity status of European Conservation Sites. Conservation, R.t.t.E.E.A.o.b.o.t.E.T.C.o.N.).

Simboura, N. \& Reizopoulou, S. (2007). A comparative approach of assessing ecological status in two coastal areas of Eastern Mediterranean. Ecological indicators, 7, 455468.

Telleria, J.L. \& Santos, T. (2001). Fragmentación de hábitats forestales y sus consecuencias. En: Ecosistemas Mediterráneos. Análisis funcional. (Consejo Superior de Investigaciones Científicas y Asociación Española de Ecología Terrestre, Madrid. pp. 293-317.

Van Wagner, C.E. (1982). Practical aspects of the line intersect method. Canadian Forestry Service, Chalk River, Ontario, Canada.

Velázquez, J., Tejera, R., Hernando, A. \& Nuñez, M.V. (2010). Environmental diagnosis: Integrating biodiversity conservation in management of Natura 2000 forest spaces. Journal for Nature Conservation, 18, 309-317.

Woodall, C.W., Rondeux, J., Verkerk, P.J. \& Stahl, G. (2006). Estimating Dead Wood During National Forest Inventories: a Review of Inventory Methodologies and Suggestions for Harmonization

En: Proceedings of the Eighth Annual Forest Inventory and Analysis Symposium. 
Woodall, C.W. \& Williams, M.S. (2005). Sampling Protocol, Estimation and Analysis Procedures for the Down Woody Materials Indicator of the FIA Program. United States Department of Agriculture (USDA), Forest Service. 